\title{
Banking Services Improvement through the Development of Service Technologies
}

\author{
Tatiana V. Zaitseva ${ }^{1}$, Gennady A. Buryakov ${ }^{1} \&$ Zhanna V. Gornostaeva $^{1}$ \\ ${ }^{1}$ Institute of service and business (branch), Federal State Budget Educational Institution of Higher Professional \\ Education "Don State Technical University", Shachty, Russia \\ Correspondence: Zhanna V. Gornostaeva, 346500, Rostov district, Shachty, Shevchenko st., 147, Russia. Tel: \\ 79-28-151-0708. E-mail: zh.gornostaeva@mail.ru
}

\author{
Received: June16, 2014 Accepted: July 16, 2014 Online Published: November 14, 2014 \\ doi:10.5539/ass.v10n23p151 URL: http://dx.doi.org/10.5539/ass.v10n23p151
}

\begin{abstract}
The authors analyze the qualitative changes in the nature and orientation of modern society, which led to the emergence of the phenomenon of "customization" and analyze the features of a modern "service of civilization". The authors use the technique of ABC-and XYZ-analysis to assess the assortment policy in banks. The article defines the external factors and the theoretical and methodological background of innovative changes in the banking market. The article also discusses the most promising innovative service technologies in the banking market and the examples of their implementation of Russian and foreign banks. To identify the main characteristics of banking products to help meet customer demand, the authors are guided by the model N. Cano, who formulated the "theory of attractive quality" and highlighted the major kinds of needs. Based on analysis of trends in the global economy, the authors concluded the growing role of the Internet in the development of service technology in the banking market and the need for further use of its opportunities for improvement of banking services. This paper investigates the key challenges and prospects for the development of service technologies and their impact on the development of banking services.
\end{abstract}

Keywords: assortment politics, ABC-analysis, banking services, N. Kano model, service technologies, XYZ-analysis

\section{Introduction}

Qualitative changes in the nature and orientation of modern society that took place in the XX century, led the chronology of successive change of specific economic development models and paradigms appropriate management of economic entities.

Phenomenon, won the world's scientific literature on the topic business called "customization" means a special, individualized approach to meeting the needs of the individual customer and is considered the ideal interaction between the "service provider-client". He is not only attractive for ethical reasons, but also economically beneficial because it provides a competitive advantage through the creation of higher value (value) for the client. This concept has received the scientific development of a number of researchers called "service factory", applies in addition to any service sector business activity, and the application of appropriate principles and methods of work is considered as due to the need for competition, often called the service imperative (Al-Hawari et al., 2005).

In this regard, the production of services, designed essentially to serve the customer to meet their basic personal or corporate needs, becomes dominant for the management of modern organizations, its concepts, methods and techniques and determines the competitive strategies based on the skills and ability to provide quality service. Society whose institutions, primarily economic, are ready to implement such approaches, it is in the true sense of service, and economy of industrial converted into service.

The emergence and development of services markets, increased competition for customers give a new, qualitatively different than before, meaning the activities of enterprises require their orientation not only at public inquiries, but - above all - to the personal needs of the person. "Service civilization" radical change world leaders and managers of enterprises. We need for new mentality, different abilities and organizational forms. The main difference between the service and industrial economy are as follows. 
If the industrial economy manufacturers aim at maximizing production output; usefulness of the concept is identified with a tangible product; Quality is synonymous with "well made"; core technology focus in the transformation of raw materials into finished products; Management is "mechanistic" character due to excessive ordering and hierarchical organization, the service economy businesses are striving to improve the usefulness of the effect by better meet the specific needs of the client; utility depends on the nature of use and the level of perfection of the so-called service product - a standalone service or system involving physical product and related services; in terms of quality we are talking about establishing an interactive relationship with the consumer that maximizes the degree of his satisfaction; core technology related to the supply of services and operation of material and service systems; management decision-making is fast, flexible and network organization.

Servization social production and consumption is most clearly manifested in the development of the service sector. Processes of servization of the economy are universal: they apply to all subjects of the economic life of society, including the end user (the person). Quality of life in the service economy is largely determined by quantitative and qualitative characteristics produced and consumed services, including financial, particularly banking.

\section{Method}

This study uses a technique of ABC-and XYZ-analysis to assess the assortment policy in banks.

$\mathrm{ABC}$ analysis is a method that allows you to explore the range of banking services to determine their rating with the greatest economic significance for the organization. The basis of this analysis is based on the Pareto principle, formulated by the Italian economist Vilfredo Pareto, namely:

- $20 \%$ range, in the group A (it is in the best case, and then 15,10 and $5 \%$ ), bring $50 \%$ of turnover and $80 \%$ of the profits;

- $50 \%$ range, in the group B, $40 \%$ bring turnover and $30 \%$ of the profits;

- $30 \%$ range (group C, in its composition may also include a range of up to $65 \%$ ) bring $10 \%$ of turnover and loss of form that reduces profits.

On the example of the bank will hold $\mathrm{ABC}$ analysis range of banking services. Objective analysis - optimization range of banking services. The analysis examined six major product groups of banking services, the bank made. For more in-depth and accurate analysis of the data were considered revenue for each type of banking services for the four quarters in 2013 (Birch \& Young, 1997).

When analyzing the range of banking services are allocated groups A, B, C, corresponding to specific assortments positions that allow you to bring the share of financing for the production of banking services and income from their sale to respectively 80,90 and $100 \%$.

$\mathrm{ABC}$ analysis is based on dividing the target population into groups according to the specific gravity of a trait. In our example, the division into groups is made according to the proportion, engaged in banking services in the total amount of proceeds from the sale of banking services, while this share should be calculated on a cumulative total.

Group A will include banking services, the amount of shares with a cumulative total which is the first $80 \%$ of the total proceeds from the sale of banking services to the group - from $80 \%$ to $95 \%$ in group C - the remainder of the amount of shares with cumulative which is from $95 \%$ to $100 \%$. Given this, the whole range of banking services can be divided into groups according to the degree of importance:

- Group A - very important banking services, which must always be present in the range. If the parameter used in the analysis proceeds from the sale of banking services, this group includes leaders of sales;

- Group B - Banking average degree of importance;

- Group C - the least important banking services, applicants for this exception to the range.

To carry out the ABC-analysis the authors construct Table 1.

By counting the number of items of banking services, calculate their share of the group: A - $16.7 \%$ B - 33.3\%, C - $50 \%$. Thus $16.7 \%$ of the range of banking services in the group A, the organization brings $63.34 \%$ of sales of banking services, it is the most revenue compared to other services.

In group B included $33.3 \%$ of the range of banking services which accounted for $27.4 \%$ of sales of banking services. Banking services are included in this group, the average contribution to promote income retail organizations. Revenue from these relatively constant, that is implemented consistently banking (Berger, 2003). 
Table 1. ABC analysis of banking services

\begin{tabular}{ccccc}
\hline $\begin{array}{c}\text { Name of } \\
\text { banking service }\end{array}$ & $\begin{array}{c}\text { Proceeds from sale of } \\
\text { banking services in 2013, } \\
\text { millions of rubles }\end{array}$ & $\begin{array}{c}\text { Share in the proceeds } \\
\text { from the sale of } \\
\text { banking services }\end{array}$ & $\begin{array}{c}\text { Revenue contribution from } \\
\text { implementation of banking } \\
\text { services with a cumulative } \\
\text { total }\end{array}$ & $\begin{array}{c}\text { Group } \\
\text { In total }\end{array}$ \\
Crediting & 3629.70 & $100.00 \%$ & $63.34 \%$ & $\mathrm{~A}$ \\
Banking cards & 2299.04 & $63.34 \%$ & $84.86 \%$ & $\mathrm{~B}$ \\
Deposits & 781.11 & $21.52 \%$ & $90.74 \%$ & $\mathrm{C}$ \\
Current & 213.43 & $5.88 \%$ & $95.36 \%$ & $\mathrm{C}$ \\
accounts & 167.70 & $4.62 \%$ & $97.78 \%$ & $\mathrm{C}$ \\
Currency & 87.84 & $2.42 \%$ & $100.00 \%$ & \\
transactions & 80.58 & $2.22 \%$ & & $\mathrm{C}$ \\
Remittances & & & & $\mathrm{C}$ \\
\hline
\end{tabular}

Group C includes all other banking services, their contribution to the revenue does not exceed 4.64\%. Leadership of the organization must examine the feasibility of production of the banking group and decide to reduce their range in order to avoid extra costs and free trade area for the more sought-after banking services.

With all the numerous advantages $\mathrm{ABC}$-analysis, there is one significant disadvantage: this method does not allow evaluate seasonal fluctuations in demand for banking services. Therefore, a logical continuation of this analysis is XYZ-analysis, whose main purpose is to find out how stable demand for banking services. XYZ-analysis allows us to share in the degree of banking stability in sales and the level of volatility of consumption.

The method of this analysis is to calculate the position of each coefficient of variation or fluctuation rate. This ratio indicates the deviation from the average flow rate value, and is expressed as a percentage. The parameter can be: sales or revenues from the sale of banking services. XYZ-analysis result is the grouping of banking services in three categories, based on the stability of their implementation.

If we consider the demand for banking services for a long period, with the help of analysis can establish that among them are banking with a permanent and stable demand - they belong to the group X, banking services, the demand for which ranges (seasonal variations) but predictable patterns of change - group Y, and finally, banking services, the demand for which is unstable (is random), and the laws of its unpredictable fluctuations - the group Z.

With this type of analysis is also singled out six banking groups on the basis of the coefficients of variation, i.e. deviation from the average value of sales. For banking group X coefficient of variation should not exceed $10 \%$, which means that the banking services are characterized by stability and sales opportunities as a result of high sales forecast. Category $\mathrm{Y}$ is determined by the coefficient of variation of $10-25 \%$, i.e. banking services in this category are the average fluctuations in demand. Banking services belonging to the group Z, have irregular consumption, so the coefficient of variation greater than $25 \%$. On an example, consider the level of stability in demand for banking services (Table 2).

Table 2. XYZ-analysis of banking services

\begin{tabular}{cccccc}
\hline Name of banking & $\begin{array}{c}\text { Proceeds from sale } \\
\text { of banking services } \\
\text { in 2013, millions of } \\
\text { rubles }\end{array}$ & Average value & $\begin{array}{c}\text { Intermediate } \\
\text { value }\end{array}$ & $\begin{array}{c}\text { Coefficient of } \\
\text { variation }\end{array}$ & Group \\
\hline In total & 3629.70 & 907.43 & & & \\
Crediting & 2299.04 & 574.76 & 1249.33 & $6.15 \%$ & $\mathrm{X}$ \\
Banking cards & 781.11 & 195.28 & 434.41 & $10.67 \%$ & $\mathrm{Y}$ \\
Deposits & 213.43 & 53.36 & 115.85 & $20.17 \%$ & $\mathrm{Y}$ \\
Current accounts & 167.70 & 41.93 & 4.65 & $5.14 \%$ & $\mathrm{X}$ \\
Currency transactions & 87.84 & 21.96 & 9.85 & $14.29 \%$ & $\mathrm{Y}$ \\
Remittances & 80.58 & 20.15 & 3.96 & $9.88 \%$ & $\mathrm{X}$ \\
\hline
\end{tabular}


$\mathrm{XYZ}$-analysis results suggest the following conclusions:

- group $\mathrm{X}$ includes banking services, which are characterized by stable sales: cutting fabrics. Minor fluctuations in demand, the demand is stable;

- group Y entered banking with fluctuations in demand and as a consequence, the average sales forecast: hairdressing, gift decoration, repair garments;

- group $\mathrm{Z}$ is absent, it shows that banking with irregular consumption absent.

The combination of $\mathrm{ABC}$ and $\mathrm{XYZ}$ analysis reveals the undoubted leader in the implementation of banking services (group AX) and outsiders (CZ). Both methods complement each other well. If ABC analysis allows us to estimate the contribution of each type of banking services in net sales, the XYZ-analysis to evaluate the marketing and racing his instability. Results of the combined analysis can be used to optimize the range of banking services, the assessment of profitability of each type of banking services (Table 3 ).

Table 3. Combination of $\mathrm{ABC}$ and $\mathrm{XYZ}$ analysis of banking services

\begin{tabular}{|c|c|c|c|c|c|c|c|}
\hline $\begin{array}{l}\text { Name of } \\
\text { banking } \\
\text { service }\end{array}$ & $\begin{array}{l}\text { Proceeds } \\
\text { from sale of } \\
\text { banking } \\
\text { services in } \\
2013, \\
\text { millions of } \\
\text { rubles }\end{array}$ & $\begin{array}{l}\text { Share in the } \\
\text { proceeds } \\
\text { from the } \\
\text { sale of } \\
\text { services }\end{array}$ & $\begin{array}{l}\text { Share in the } \\
\text { proceeds from } \\
\text { the sale of } \\
\text { banking } \\
\text { services with a } \\
\text { cumulative total }\end{array}$ & Group & $\begin{array}{l}\text { Coefficient } \\
\text { of variation }\end{array}$ & Group & Combination \\
\hline In total & 3629.70 & $100.00 \%$ & & & & & \\
\hline Crediting & 2299.04 & $63.34 \%$ & $63.34 \%$ & A & $6.15 \%$ & $\mathrm{X}$ & $\mathrm{AX}$ \\
\hline $\begin{array}{l}\text { Banking } \\
\text { cards }\end{array}$ & 781.11 & $2 ., 52 \%$ & $84.86 \%$ & B & $10.67 \%$ & Y & BY \\
\hline Deposits & 213.43 & $5.88 \%$ & $90.74 \%$ & B & $20.17 \%$ & Y & BY \\
\hline $\begin{array}{l}\text { Current } \\
\text { accounts }\end{array}$ & 167.70 & $4.62 \%$ & $95.36 \%$ & $\mathrm{C}$ & $5.14 \%$ & $\mathrm{X}$ & CX \\
\hline $\begin{array}{l}\text { Currency } \\
\text { transactions }\end{array}$ & 87.84 & $2.42 \%$ & $97.78 \%$ & $\mathrm{c}$ & $14.29 \%$ & Y & CY \\
\hline Remittances & 80.58 & $2.22 \%$ & $100.00 \%$ & c & $9.88 \%$ & $\mathrm{X}$ & CX \\
\hline
\end{tabular}

Based on the results, as reflected in Table 3, we can conclude that in general the range of banking services for retail organizations has a uniform, stable demand and sales revenue. The presence of type AX means that in the range of banking services have services that bring a large stable income.

\section{Results}

Innovations in the present are not just one of the phenomena that determine economic growth, development and structural changes. Innovation has become the essence of modern development in all spheres of the economy, including banking. Under the influence of external factors in the comprehensive banking practices occur following innovative changes (Bhat, 2005).

- New banking products (services) on the basis of new information technologies.

- Virtual banking and financial technology: managing a bank account, cash transactions, electronic signatures, contracts, financial institutions (stock exchanges, banks).

- integrated use of new information and communication technologies for electronic and mixed (traditional and new) marketing.

- The collection, storage and analysis of internal information processing.

- New features of the internal control and audit.

- Changes in the training of employees: product manager, consultant, specialist consultations and transactions.

- The new self-service machines (mono and multifunctional, information).

The result is a change in the structure and appearance of the bank's overall "multi activity" with a combination of new and traditional technologies and tools; self; remote maintenance; use of the Internet, call centers, 
In connection with the global Internet penetration in all spheres of our life one of innovation was the use of social networks and banks on-line-games to expand the market for its services. One of the most popular in the world, and now ready to launch in Russia are RFID technology and NFC.

Recent decades have been a period of introduction of new computer technology, credit cards and important innovations monetary and financial market. These include hedging instruments of banking risks, credit derivatives, Internet, smart cards. They can be characterized by innovation in the banking sector as a result of the innovative activities of the bank, brand new set of banking products and services. Banking innovation is a synthetic concept of the purpose and results of operations in the field of new technologies aimed at obtaining additional income in the process of creating favorable conditions for the formation and location of the resource potential of using the introduction of innovation supporting customers in making a profit.

New banking product - combined or alternative form of banking, created on the basis of market research needs of the market. New product can be a bank, credit and financial instrument. Thus, in 1752 as a reaction to any checks on banks ban the British government to issue banknotes by credit institutions, payable on demand at the box office. In 1958 was released the first mass bankcard Bank Americard (modern Visa), provides the ability to extend credit (credit card). Prior to this card scheme were local. In Russia, the international card systems appeared in 1969, but at that time it was the cards issued by foreign companies and banks. In February 1961, the U.S. appeared key innovation of modern banking - the first certificate of deposit. Currently, the concept of deposit and savings certificates reflected in the Civil Code.

At the heart of the creation of new banking products and the introduction of innovative services based on the following theoretical and methodological assumptions:

- formed a new paradigm of innovative development of the economy;

- banking innovations are part of the total flow of innovations that have become typical for a modern economy;

- banking innovations are divided into product and technology; core product strategy is the current account / debit card;

- information technology has become a universal banking business environment;

- remote banking customer service based on Internet technologies, without a doubt, should be one of the main forms of retail banking services; in 2013 the possibility of Internet banking in Russia used more than 2 million people - most of them are customers of several large banks;

- information conception banking network begins to fade into the background, and first place is its use as an integrating tool of human activity;

- one of the clearest examples of the introduction of the banking strategy is the use of innovative changes in Russian banks lean-approach.

To identify the main characteristics of banking products to help meet customer needs, should be guided by the model N. Cano, who formulated the "theory of attractive quality" and singled out the following types of needs:

- expected (expected), the satisfaction of which necessarily and obviously for the consumer;

- your (desired). The better meet these needs, the more satisfied the consumer;

- admire the (exited). Their satisfaction delights the consumer, as he did not expect this.

Spreading on banks identified logical relationships between customer needs and product quality, we can make the following assumptions. And admire your client's needs are met through additional services included in the mix of banking products. For example, the need for corporate clients in personal service met by Private banking, other clients need the services of cash management services outside the office - through remote banking.

Remote management of bank accounts can be done in different ways:

- by phone - telebanking (telebanking);

- PC - e-banking (e-banking);

- Internet - Internet banking (Internet banking);

- portable devices - mobile banking (mobile banking, m-banking).

In connection with the transfer of the center of gravity on the remote service function of the existing retail network narrowed gradually and increasingly resemble branches specialized service centers. The evolution of the banking system in the direction of remote banking model is due to a number of objective features of the economic and social environment in which there are banks in the first place - changes in people's lifestyles, the introduction of new information technologies and automation of banking operations, increasing competition.

During the financial crisis, Sberbank became the first Russian bank to start in June 2008 introduction of the program lean (in translation from English. Lean management - "Lean Management"). LEAN - a methodology, 
implementation and use in their daily work which gives you the opportunity to get rid of unproductive processes, actions, inefficient use of space and staff time.

For employees in the branch of Sberbank in Biryulevo of Moscow experiment began in May 2008 It was then working group had the timing of the main processes by which waste time tellers: sber-cards replacement, prompt transfers, utility payments, cash transactions, registration of plastic cards, payment of compensation, opening and closing of the trading day, the formulation of consumer loans. As a result, were chosen to optimize several directions -replacement sber-cards, compensation payments and currency exchange.

The experiment failed to achieve qualitative improvements: halve the waiting time, flatten peak "sagging" of customers by eliminating the lunch break and the universalization of windows operating, reduce the time of the transactions. As part of the quantitative results, it is worth noting a doubling of growth receiving utility payments, a 7.5-fold increase in non-interest income blitz transfers compared with the control group, significant savings boom-gi. For example, the process of replacing the passbook was reduced from 20 required steps, which spent 3.5 minutes to 40 seconds, to fit five actions.

In Moscow today, is considered sufficient to manage the replacement with a single blow hole punch, the other four operations considered superfluous. When compensation (balance of deposits in the Savings Bank of the USSR for 1991), the procedure of obscure client "running around" - for the roster of contributors, for senior-change - and completing the form, where half of the graph is not clear, reduced to answering questions teller who fills out the form itself, will not leave. Calculation and validation of bills instead of three different operations on three different machines were reduced to one on the universal machine. In Nizhny Novgorod office since the start of the program duration MSS trading day closing procedures halved - from 4.5 to $2 \mathrm{~h}$ with a small staff and hope to soon bring it to an acceptable standard - 1.5 hours

Each Regional Bank opened two or three experimental office, which organized the training of employees. As a result, the bank expects 30\% increase in productivity. Frees up time bank employees directed at the promotion of sophisticated banking products, workplace learning and improving the quality of service. LEAN-application technologies in Western banks and companies is becoming an increasingly popular. Some of them are self-introduction of lean technologies, others invite consultants. As a rule, corporations and banks to apply these technologies to solve some specific problems. For example, the Nordic financial group Nordea has developed an agenda for change, to free up time in client managers. Application of LEAN-technology today gives tangible results.

Thus, innovation in the banking sector in the context of globalization - the urgent need for Russian banks. To survive in the global competition, the need for Russian banks are oriented only on the most advanced technologies and products. Crucial role currently played by innovative technology. Innovative technology, which is already being tested, can be called wireless technology NFC (Near Field Communication). NFC can be literally translated as "near field communication"), which is based on the use of ideology radio data on the principles of mutual induction for short distances in the frequency range of $13.56 \mathrm{MHz}$. NFC and RFID act by analogy with WI-FI and Bluetooth, but have fundamental differences (Shoebridge, 2005).

In Russia, the first example of the use of NFC technology was to demonstrate the use of NFC-enabled phones to pay for travel on the Moscow Metro subway station at the opening of "Pipe". That is the widespread use of this technology would replace paper money. Activities of credit institutions in the banking market provide an extension to the supply and demand for banking products, as part of traditional and innovative technologies for their conduct.

In the modern sense of a new banking service - is the result of the collective activities of the bank to provide aid or assistance to the client in making a profit, can yield major operator diet and add an additional net income for a sufficiently long period of time. In this definition, we consider the banking service from a position as a result of an integrated approach, bringing the bank the primary and secondary net income, i.e. income excluding significant implementation costs, and at the same time take into account the time factor.

New vision of the scope of banking services based on the concept of "Bank of the Future". When creating the bank of the future innovative technologies in banking services - these are technologies that have "strategic effect" increase customer base, attracting significant persons, reducing servicing costs of banking operations at the optimal level of operational risk and operational costs. NFC technology has been developed by Philips and Sony in 2002 as an evolutionary combination of contactless identification technology and communication technology. NFC provides a convenient, reliable and secure data transmission over the air for short distances between various electronic devices that combine functions contactless reader and contactless cards, as well as able to communicate with each other as peers (Centeno, 2004). 
The first real step toward contactless payment was made in August 2004, fast food chain McDonald's. the company entered into an agreement to receive MasterCard PayPass cards in a number of restaurants in the United States. This event has started the process of eliminating cash contactless payment cards when making transactions for small amounts. NFC opens up a huge range of options users, allowing no additional effort to interconnect digital cameras, PDAs, digital consoles, computers and mobile phones. The most common device in the world with NFC-interface today is the mobile phone. NFC has been widely used in such business areas and projects as selling various kinds of electronic ticketing and payment of public transport, entertainment, tickets booking and payment, etc.

NFC-enabled mobile phones can be used as a bank plastic card to work with ATMs. The user places the phone next to the ATM machine, which identifies the number and identity of the owner reads the protected information from your mobile phone. This information includes the account number, a predetermined maximum daily LIIT cash withdrawals and other relevant information that may be different for different banks.

As soon as you enter your PIN-code, you get access to the money in his bank account in the normal mode (you can withdraw cash, pay for any services, etc.). One of the main advantages of using NFC-enabled phones is that they can store information about several bank cards, allowing you to not carry a pack of cards. That is an inevitable consequence of the displacement becomes bankcards, through the implementation of the authentication procedure using mobile NFC-phone.

To date, Japan has begun to actively use technology NFC. Some gas stations already equipped with contactless payment terminals for the fuel with the help of NFC-Mobile, which is very convenient and saves time of the driver and passengers. In the foreseeable future payment system based on NFC can be implemented in a Japanese taxi, which means that customers do not have no-Sit with your cash. In the UK restaurant chain EAT implemented in its 88 institutions across the country contactless payment solution order (Bloemer et al., 1998).

Since the summer of 2006, the passengers of the New York subway can now use their cards for MasterCard PayPass through the turnstile at 30 stations Lexington line running through the island of Manhattan to Central Station New York City (Grand Central Station). With the help of automated payment devices and contactless interfaces of veriFone payment for the trip may be charged with a MasterCard card account in the same way as when making other purchases using the card PayPass.

Application of plastic cards to pay for travel to New York, London and Warsaw, as well as the payment of parking in Poland confirms the fact that contactless payment technology is very effective in the field of public transport. Besides the fact that they increase the speed of passenger traffic at bus stops and train stations, this form of automatic fare collection eliminates transport companies from all the complexities associated with the work with cash, as well as the risk of fraud.

Communication technology in the near zone (NFC) - is a technology standard for chips that allows to connect at very close range and enabling the user to initiate and perform contactless transactions, as well as access to digital information, such as ringtones or files for download on the mobile phones.

RFID technology (RFID) - a method of identification using silicon chip located on the label, which allow to receive a radio frequency device requests a read / write and respond to them; many believe that RFID will replace bar codes and magnetic strips. Innovation in the way of communication, data processing and technical capabilities even in unrelated areas should not be left unattended management of commercial banks (Popkova et al., 2013a).

So, Citibank is testing a new system of payments using the latest wireless technology NFC (Near Field Communication), which are embedded in the chip cell phones. The first test batch of special payment cards and cell phones began to be used in the Indian city of Bangalore. According to Citibank, the new program Citi Tap and Pay covers 5 thousand mobile phones and several major Indian shopping centers, equipped with special POS-terminals, readers information about purchases and conductive transfer.

New devices with contactless function do not need to be rolled into the payment terminal to pay for your purchase any electronic device equipped with feature NFC (eg mobile phone), the owner enough to hold them near the terminal. Further transaction map or device runs as a common operation in the usual credit card. After the "break-in" business process Citi plans to deploy large-scale action on the use of NFC (DeYoung et al., 2007).

National Bank of Kuwait (NBK), Visa, Zain telecom operator and the company had tested ViVOtech NFC_tehnology April 9, 2009 According to Khalid Al Heydzhray (Khalid Al Hajery), manager of the company Zain Kuwait: "Mobile phones are no longer just devices to commit or receiving calls. Instead, continuous 
contributions to innovation means that mobile phones are now becoming more and more a platform for new technologies, such as close payments".

Visa Inc. announced the launch of contactless payment systems based on mobile phones. While this technology is only available in Malaysia. MasterCard Worldwide in collaboration with the developer of mobile solutions BlazeMobile proposed new stickers PayPass, which can be attached to any mobile device and used to make contactless payments in 141 thousand retail and service locations around the world (Cooke, 1997).

Sticker transmits information from the card to the terminal through PoS-technology RFID. In addition to the stickers there is the development of "smart posters". They can be used to receive promotional information, flyers for bonuses and discounts, contacts and even add video and audio clips or ringtones using contactless technology transfer on a mobile phone.

The main challenges to the development of contactless payments are security and the creation of a business model. With regard to the safety of transactions on the basis of NFC, the banking community is inclined to the use of biometrics for the procedure identification of the client.

Most likely will be biometric technologies "imprint" voice and signature. Voice authentication can be carried out successfully even in the presence of cold and runny nose of the owner, and the analysis takes into account the feature of handwriting signature and pressure of the paper. Therefore, many banks already working actively biometric experiments (Mukherjee et al., 2003).

At the conference, the European Banking Association (EBA), devoted to the payments, which took place in Frankfurt in June 2006, were designated certain forward the development of innovative technologies in the banking sector. Mark Garvin, chief analyst at JP Morgan Chase AG, agreed that the payment services industry in 2016 will forget about paper checks that payments via mobile phones will become commonplace, and biometrics eliminate the possibility of fraud. Apple announced on its official website the program IChat, which allows you to broadcast videos for interpersonal communication via the Internet at the level of digital television.

For banks, this means a return to the "live" communication with the client, which was lost in the process of automation of banking operations and the technological revolution. That is, the sending client to ATMs and teaching him to independently carry out simple operations on their accounts through the Internet, through the programs of Internet banking, bankers depersonalize the process of selling their services. CRM-programs analyze customer needs and keep statistics on the use of certain services to customers, but without taking into account short-term desires, moods, circumstances have occurred in a person's life, encourage him to use or refuse to use any banking services. Due to the lack of interpersonal communication banks issued sight of the need to establish a trusting relationship with clients (Loonam \& O'Loughlin, 2008).

Given the development of all these technologies, the Internet user can once again meet with the employee of the bank face to face video call. This can be done from anywhere in the world from your computer, TV or mobile phone with high definition images. This innovative service will be called video-banking as the next evolution of mobile and Internet banking.

This service will be available on a 24-hour service. That is, the client will "own" the manager, with whom he is personally acquainted and who will know all the individual characteristics of the client service. If a bank provides video, the question arises about the number and work schedule of employees, which may be available to customers at the same time as a video. This problem can be solved through the use of realistic video avatar robot. Actions will adjust robot dialogue system using touch control dial tone on your mobile phone, interactive touch-screen HD TV, touchscreen computer (Popkova et al., 2013b).

With the development of the next generation control system will be built already in sensor technology and mechanisms to recognize voice commands. That is, once recorded video answers a personal manager for possible standard client requests, such as balancing accounts, recent transactions, etc., will allow customers to "meet" with his manager 24 hours a day.

\section{Discussion}

The analysis results showed that:

- banking groups A and B are the most revenue in comparison with other service activities, so you must ensure that their constant presence;

- banking group AX have more revenue from sales and sales stability. Implementation of this banking group is stable and well predicted;

- banking groups BY high sales revenues have insufficient stability of implementation; 
- share in revenue banking group C does not exceed 4.64\%, so the leadership of the organization of trade must examine the feasibility of production of the banking group and decide to reduce their range in order to avoid extra costs and free trade area for the more sought-after banking services;

- for banking services that are included in the group CX and CY can use ordering system;

- lack Group CZ, suggests that spontaneous demand banking services in the organization of trade absent.

The proposed method of analysis of the range of banking services, you can:

- examine the profitability and efficiency of service activities in trade organizations;

- estimate the contribution of each type of banking services in the revenue from sales of goods, works and services;

- to evaluate the uniformity of sales;

- used to optimize the range of banking services.

Banks that can keep pace with technological progress: it is timely to develop business processes, update the software, making it adaptable to virtual services, get a distinct advantage over other market participants. Hardware independent High-Speed Internet allows the user using any wireless device or mobile access to services in a mode on-line around the clock 365 days a year (Kozak, 2005). Only banks that will be willing to continuously online service will be able to survive the technological revolution. Therefore, the main aspect of the competition will be the size of investment in the development and implementation of information technologies that meet the requirements and market. For successful participation in the competition, in your opinion, you need to solve the following problems:

- increase flexibility and adaptability to the market, not only to introduce a fundamentally new technology, but also develop a "kaizen-approach" (a philosophy that focuses on continuous improvement of all aspects of life);

- go to the new self-service computer technology, remote maintenance, virtual banking and financial technology;

- develop and introduce new loan products based on new technologies; meet customer needs as follows: expected - due to the necessary characteristics; desired - at the expense of one-dimensional; admire the due to attractive quality of the product;

- integrated use of new information and communication technologies for e-marketing;

- innovate in the field of forms and methods of management, changes in the training of employees; in the management of innovation abroad model was developed to meet the needs of customers, called Kano model.

- $\quad$ keep in mind that technological innovation can reduce the effectiveness of control of the banks by the Central Bank of the Russian Federation.

Under these conditions, the improvement of banking services through the development of service technology becomes simply necessary for competitiveness and development of the bank's banking market.

\section{References}

Al-Hawari, M., Hartley, N., \& Ward, T. (2005). Measuring banks automated service quality: A confirmatory factor analysis approach. Marketing Bulletin, 16, 25-29.

Berger, A. N. (2003). The economic effects of technological progress: Evidence from the banking industry. Journal of Money, Credit, Banking, 35(2), 141-176. http://dx.doi.org/10.1353/mcb.2003.0009

Bhat, M. A. (2005). Correlates of service quality in banks: An empirical investigation. Journal of Services Research, 5(1), 77-99.

Birch, D., \& Young, M. A. (1997). Financial Services and the Internet - What does Cyberspace mean for the Financial Services Industry? Internet Research: Electronic Networking Applications and Policy, 7(2), 120-128. http://dx.doi.org/10.1108/10662249710165262

Bloemer, J., de Ruyter, K., \& Peeters, P. (1998). Investigating drivers of bank loyalty: The complex relationship between image, service quality and satisfaction. International Journal of Bank Marketing, 16(7), 276-286. http://dx.doi.org/10.1108/02652329810245984

Centeno, C. (2004). Adoption of Internet Services in the Acceding and Candidate Countries, Lessons from the Internet Banking Case. Telematics and Informatics, 1, 293-315. http://dx.doi.org/10.1016/j.tele.2004.02.001

Cooke, S. D. (1997). Structural change in the US banking industry: The role of information technology. Washington: US Department of Commerce, 29(1), 16-21. 
DeYoung, R., Lang, W. W., \& Nolle, D. L. (2007). How the Internet affects Output and Performance at Community Banks. Journal of Banking \& Finance, 31(1), 1033-1060. http://dx.doi.org/10.1016/j.jbankfin.2006.10.003

Kozak, S. (2005). The role of information technology in the profit and cost efficiency improvements of the banking sector. Journal of Academy of Business and Economics, 2(1), 34-38.

Loonam, M., \& O'Loughlin, D. (2008). An Observation Analysis of e-service quality in in Online Banking. Journal of Financial Services Marketing, 13(2), 164-178. http://dx.doi.org/10.1057/fsm.2008.13

Mukherjee, A., Nath, P., \& Pal, M. (2003). Resource, service quality and performance triad: A framework for measuring efficiency of banking services. Journal of the Operational Research Society, 54(7), 723-735. http://dx.doi.org/10.1057/palgrave.jors.2601573

Popkova, E., Akopova, E., Alekhina, E., Dubova, J., Popova J., Avdeeva I., \& Proskurina, I. (2013b). Methodology of development of strategy of development of economic systems. World Applied Sciences Journal, 26, 489-493.

Popkova, E., Morkovina, S., Patsyuk, E., Panyavina, E., \& Popov, E. (2013a). Marketing strategy of overcoming of lag in development of economic systems. World Applied Sciences Journal, 26, 591-595.

Shoebridge, M. (2005). Banking on six sigma to improve service quality a case study: Major Australian financial institution. Australian Banking \& Finance, 14, 9-10.

\section{Copyrights}

Copyright for this article is retained by the author(s), with first publication rights granted to the journal.

This is an open-access article distributed under the terms and conditions of the Creative Commons Attribution license (http://creativecommons.org/licenses/by/3.0/). 